\title{
The Vicious Circle of Post-Soviet Neopatrimonialism in Russia
}

\section{Gel'man, Vladimir}

2015-08

Gel'man , V 2015 , ' The Vicious Circle of Post-Soviet Neopatrimonialism in Russia ' , Post-Soviet Affairs , vol. 32 , no. 5 , pp. 455-473 . https://doi.org/10.1080/1060586X.2015.1071014

http://hdl.handle.net/10138/223807

https://doi.org/10.1080/1060586X.2015.1071014

unspecified

acceptedVersion

Downloaded from Helda, University of Helsinki institutional repository.

This is an electronic reprint of the original article.

This reprint may differ from the original in pagination and typographic detail.

Please cite the original version. 


\section{Vladimir Gel'man ${ }^{1}$}

The Vicious Circle of Post-Soviet Neopatrimonialism in Russia

Abstract. Since the collapse of Communism, Russia and some other post-Soviet states have attempted to pursue socio-economic reforms while relying upon the political institutions of neopatrimonialism. This politico-economic order was established to serve the interests of ruling groups and establish the major features of states, political regimes, and market economies. It provided numerous negative incentives for governing the economy and the state due to the unconstrained rent seeking behavior of major actors. Policy reform programs discovered these institutions to be incompatible with the priorities of modernization, and efforts to resolve these contradictions through a number of partial and compromise solutions often worsened the situation vis-à-vis preservation of the status quo. The ruling groups lack incentives for institutional changes, which could undermine their political and economic dominance, and are caught in a vicious circle: reforms often result in minor returns or cause unintended and undesired consequences. What are the possible domestic and international incentives to reject the political institutions of neopatrimonialism in post-Soviet states and replace them with inclusive economic and political ones?

Keywords: neopatrimonialism, political institutions, governance, authoritarianism, Russia

${ }^{1}$ Vladimir Gel'man (gelman@eu.spb.ru) is Professor at the European University at St Petersburg and Finland Distinguished Professor at the Aleksanteri Institute, University of Helsinki. This article is a part of the research project "Choices of Russian Modernization" funded by the Academy of Finland. I would like to thank Pami Aalto, George Breslauer, Egor Lazarev, Mikhail Sokolov, and Dmitry Travin for useful comments to earlier versions of the text. 
The Vicious Circle of Post-Soviet Neopatrimonialism

The almost quarter century of post-Communist political, social and economic changes that has elapsed in Russia and some other states of post-Soviet Eurasia has brought mixed results at best. Even if one were to put aside the dramatic wave of conflicts after the Russian annexation of Crimea in 2014 and the subsequent confrontation with the West, these results can be seen as a low-level equilibrium in several areas. If we assess these changes through the lens of "triple transition" (Offe, 1991) as a modernization in the three dimensions of democratization, market economy, and state- and nationbuilding, their overall consequences appear rather contradictory. Post-Soviet political regimes represent multiple varieties of authoritarianism, both "hegemonic" and "electoral" versions (Howard, Roessler, 2006; Levitsky, Way, 2010; Gel'man, 2014). Post-Soviet market reforms contributed to the rise of patrimonial "crony capitalism", which is based upon ruling groups' political control over key economic assets and economic actors (Schlumberger, 2008; Robinson, 2011). The quality of governance in Russia and other post-Soviet states is much poorer than one might expect given their degree of socio-economic development (Worldwide, 2014), while the rent seeking by their ruling groups is nearly universally condemned by all observers regardless of their views on other issues. This triad of authoritarianism, crony capitalism and bad governance is closely interdependent and interconnected, so it would not be a wild exaggeration to argue that the results of post-Soviet changes in Russia are systemic and self-reproducing, at least in the short run.

Although optimistic scholars argue that economic growth and generation changes of political leaders might result in major advancements in Russia and other post-Soviet countries over the next few decades (Shleifer, Treisman, 2014; Treisman, 2014), the question of the causes and mechanisms of the current trajectories of post-Soviet Russia is still relevant. Answering it would require a closer look at the institutional foundations of post-Soviet modernization and the logic and peculiarities of patrimonial governance, which has posed major constraints to policy reforms and has contributed to unintended (and often undesirable) consequences of these changes.

\section{Introduction: Russia's Greatest Rent Machine}

For New Year's Eve 2015, the residents of more than two dozen Russian regions received an unexpected and unpleasant holiday gift from the authorities. They were notified that the commuter trains (elektrichki) which link many cities and towns with regional capitals were being cut en masse; in some regions they were completely abolished. Although the frequency of commuter trains had already been reduced, simultaneously with a steady rise in ticket prices, the elimination of many trains at once caused major public discontent, especially in those areas where no other public transportation had been provided. Soon after, one of the leaders of the Russian opposition, Alexei Navalny, accused both the authorities and the top managers of Russian Railways holding (RZhD) of "genocide of the Russian people" (Navalny, 2014), while in some Siberian regions attempted collective action by local residents contributed to threats of rail traffic blockages. The rise in social tension became so striking and visible that in February 2015 Russian President Vladimir Putin, speaking before TV cameras, asked state officials and the RZhD leadership to restore commuter 
trains in full. Shortly afterwards, the return of passenger traffic was announced in the media (although in reality, it was only a partial return), so the previous status quo was restored, at least for a while.

The abolition of commuter trains was a logical outcome of the changes to Russian railways which had been implemented during the previous decade (Pittman, 2013; Gaaze, 2015; Khusainov, 2015; Navalny, 2015a). In 2003, in accordance with a decree by Putin, the long-existing Ministry of Railways (MPS) was transformed into the stateowned company $\mathrm{RZhD}$, which received the key assets of the railroad sector; later on it became a joint stock company. Subsequently, the Russian railroads underwent a series of structural reforms intended to liberalize the sector. Many reform projects, oriented to follow best international practices (Pittman, 2013; Khusainov, 2015), proposed that $\mathrm{RZhD}$ should separate profitable cargo transportation from unprofitable passenger traffic, while state policies should pave the way toward a competition of private companies on the market. But in reality RZhD not only preserved but even strengthened its monopolist position; it de-facto dictated outstandingly high tariffs and requested that the state cover the increasing losses of its subsidiary companies, which were in charge of operating commuter trains. These companies, in turn, leased trains and rails from $\mathrm{RZhD}$ and paid it outstandingly high fees for the use and service of trains (owned by $\mathrm{RZhD}$ ), while their losses were compensated in full from the budget. In 2011, the responsibility for covering these losses was transferred to the regional authorities, which do not have the funds to feed RZhD's appetites (and in fact have to cover many other expenditures due to previous requests from the federal authorities) ${ }^{2}$ and lack the capacity to resist RZhD. Moreover, in January 2015, in accordance with RZhD's request, the federal government drastically increased fees for the use of rail infrastructure, thus aggravating the financial burden on regional authorities to subsidize commuter trains (Navalny, 2015a). Putin's subsequent call for action did not change the economic model of commuter trains; at best, responsibility to cover losses was transferred from regional budgets to federal coffers (with the annual amount estimated at 22 billion rubles), but the taxpayers were still having to pay any bills presented by $\mathrm{RZhD}$.

Although experts rightly observe that the problem of subsidizing unprofitable yet socially important commuter trains is hardly unique to Russia, and relevant for railroad reforms elsewhere (Pittman, 2013), the case of RZhD was atypical not only due to the scope of these problems but also due to their solution. In essence, reforms resulted in the transformation of a state agency, MPS (a legacy of a centralized planned economy), into a gigantic monopoly, $\mathrm{RZhD}$, which was formally owned by the state and operated on the market, but was in practice outside state control, and which operated for the benefit of its top managers. Vladimir Yakunin, the CEO of this holding, was one of the key members of Putin's "inner circle" (Petrov, 2011) and famous not only because of his conspicuous consumption of luxury material goods (his big estate near Moscow has been nicknamed "fur storage", or shubokhranilishche) but also because of his spike in international status as a public intellectual. Yakunin, a doctor of political sciences who chaired the department of state governance at Moscow State University, is a patron of the Russian Society of Political Scientists and President of the World Public Forum

\footnotetext{
${ }^{2}$ The regional budgets bear responsibility for implementation of Vladimir Putin's May 2012 decrees, which called on regional authorities to achieve a major rise in public sector employees' salaries without an increase in budgetary revenues, so many other expenditures (including subsidizing commuter trains) were inevitably cut.
} 
"Dialogue of Civilizations", which has held numerous international events with participation from global celebrities, and even sponsored publication of a book, Conversations with the World's Foremost Thinkers, where Yakunin was included alongside some of Nobel Prize winners (Dutkiewicz, Sakwa, 2013). Despite widespread criticism of Yakunin in the media and some attempts to cancel his job contract as CEO, close connections with Putin made him nearly invincible and gave Yakunin carte blanche; RZhD became a fiefdom of this crony of Putin, while its business operations remained in the shadow of numerous offshore companies connected with Yakunin (Navalny, 2015a).

In other words, after major reforms a formally state-owned monopoly, the biggest employer in the country, is now possessed by a private person who has turned RZhD into a tool for rent maximization and placed the burden of costs (arbitrarily set up by himself) on taxpayers' shoulders. To paraphrase the Boney $M$ hit of the 1970s, this mode of governing the railroads can be best described as "Russia's Greatest Rent Machine". Its social costs are much higher than those of the MPS model, which emerged in the 1930s under the leadership of Stalin's close subordinate Lazar Kaganovich. MPS served as one of the pillars of the Soviet economy, had priority access to state resources including labor and investments, and had relatively high status in state distribution of welfare and other goods. Later on, its role decreased because of technological changes and the decline of the Soviet economic model, and by the time of the Soviet collapse its impact on rent seeking was relatively modest. While the crisis of the MPS model in the 1990s has been widely recognized (Pittman, 2013; Khusainov, 2015), the consequences of the 2000s reforms may be considered as a turn from bad to worse.

The case of $\mathrm{RZhD}$ is not the only example of failure of one of the sectoral reforms which formed a large scale program of socio-economic changes in Russia under Putin (Alexeev, Weber, 2013; Gel'man, Starodubtsev, forthcoming). But why did the good intentions of neoliberal reforms pave a road to the hell of crony capitalism in its patrimonial form in post-Soviet Russia? I argue that the causes of these mutations of post-Soviet modernization are related to the emergence and maintenance of neopatrimonial political institutions. These institutions should not be perceived merely as inherited from the Soviet (or pre-Soviet) past; rather, they were deliberately and purposefully built after the Soviet collapse to serve the interests of ruling groups in Russia and other post-Soviet states and consolidate their political and economic dominance (North, 1990: 16). Neopatrimonialism inhibited the potential for implementation of a "narrow" program of socio-economic modernization (which would exclude political democratization from government agendas). Thus, policy reforms resulted in partial effects at best, and very often contributed to a vicious circle of socially inefficient changes which served privileged private interests. I also argue that this vicious circle cannot be broken by attempting to "borrow" socially efficient institutions or "grow" them step-by-step within the given political constraints. Further embedding of post-Soviet neopatrimonialism may increase the risk of its reinforcement and self-reproduction regardless of possible political regime changes. I believe that the incentives for rejection of neopatrimonial political institutions and their replacement by "inclusive" political and economic institutions (Acemoglu, Robinson, 2012) in Russia and other post-Soviet countries may (though not necessarily should) be strengthened by external influence, with restriction of their sovereignty and possible compulsion from advanced states and international actors. 
The structure of this article is as follows. First, after an overview of discussions of postSoviet neopatrimonialism, I present my own approach to analysis of its effects on postSoviet governance and policy-making, and its political constraints. Further, I explore mechanisms of governance within the framework of neopatrimonial political institutions (the "power vertical") and focus on the policy reforms, which have brought few returns and/or have resulted in unexpected and undesired consequences (the models of "borrowing" and "growing" institutions). In the conclusion, I discuss some implications and considerations with regard to the possibility of breaking the vicious circle of postSoviet neopatrimonialism.

\section{Sources and Substance of Post-Soviet Neopatrimonialism}

Although the labeling of the post-Soviet politico-economic order as "neopatrimonial" has become nearly ubiquitous in the numerous works on post-Soviet Eurasia (Derluguian, 2005; Fisun, 2012; Robinson, 2011, 2014; van Zon, 2008), the very term and its use as a tool for analysis need a certain clarification. Patrimonialism, according to the Weberian approach, is perceived as an instance of traditional authority, a politicoeconomic order based upon appropriation of public political and economic power for private purposes. However, neopatrimonialism is nearly by default considered to be a manifestation of this traditional order in modern societies which, contrary to Weber, is juxtaposed to legal-rational authority (Eisenstadt, 1978, ch. 17; Fisun, 2012). The category of "neopatrimonial politico-economic order" covers both political regime and model of governance and cannot be reduced to either of these elements (Robinson, 2014). Within this framework, both personalist authoritarian regimes and patrimonial crony capitalism may be considered to be results and consequences of neopatrimonialism in politics and governance respectively. In a more general sense, the neopatrimonial politico-economic order represents one variety of the "limited access order" (North et al., 2009), with a prevalence of "extractive" political (and often economic) institutions (Acemoglu, Robinson, 2012). However, these institutions (in the sense of the set of rules and norms, and the sanctions for their violation) are in a kind of symbiosis, where the legal-rational shell of formal rules of the game only conceals a neopatrimonial "core" of informal institutions (Erdmann, Engel, 2006) which have a "subversive" influence on institutional performance (Gel'man, 2012). While some experts note that this symbiosis is a source of instability for the neopatrimonial politicoeconomic order, others argue that neopatrimonial institutions maintain an inefficient yet self-enforcing equilibrium (Robinson, 2014).

Since the neopatrimonial politico-economic order is founded on elements of traditional authority, it is no wonder that its most widespread explanations relate to the effects of legacies of the past (Pop-Eleches, 2007). Neopatrimonialism is often perceived as a rudiment of traditional societies which was so deeply embedded in their social and political organization that it either cannot be eliminated in the process of modernization or becomes a kind of traditionalist reaction to modernization's failures (Eisenstadt, 1978, ch. 17). While in the case of African states (which are largely perceived as "reservations" of various forms of neopatrimonial rule) the whole frame of reference revolves around colonial legacies (Bratton, van de Walle, 1994; Erdmann, Engel, 2006), in post-Soviet Russia scholars look for sources of neopatrimonialism in virtually all stages of Russian and Soviet history. They assign responsibility for the embeddedness of neopatrimonialism to the indispensable legacy of pre-Petrine Russia with its lack of private property and arbitrary rule of autocratic leaders (Pipes, 1974), or to the legacy of 
Communist regime, which, in its late developmental stage, demonstrated decay and "degeneration" into neo-traditionalism (Jowitt, 1983). Some scholars who do not refer to neopatrimonialism in their analyses of post-Soviet politico-economic order and use other categories, ranging from "patronal politics" (Hale, 2014) to "sistema" (Ledeneva, 2013), also focus on their effects on politics and governance through the lenses of various legacies of the past. In any case, the "legacy" argument is structural in nature: explicitly or implicitly, neopatrimonialism is assumed to be like an inherited chronic disease of the socio-political organism, which cannot be cured at least in the foreseeable future.

Without denying the importance of various "legacies", one should take into account that the rise of post-Soviet neopatrimonialism in Russia and some other post-Soviet states, to a large degree, was a consequence of the purposeful actions of political and economic actors, who aimed to maximize benefits to themselves during the process of redistribution of power and resources in the turbulent post-Soviet environment. For example, in the case of $\mathrm{RZhD}$, the neopatrimonial governance of the biggest stateowned company under Yakunin's leadership has not resulted from the legacies of this sector or of the Russian economy as a whole. Neither Kaganovich nor his MPS successors ever dreamed of a degree of freedom like Yakunin's in arbitrarily governing their respective domains. Rather, RZhD has been turned into its CEO's fiefdom after the distribution of rent sources among the members of the "winning coalition" (Bueno de Mesquita, Smith, 2011) led by Putin and his close associates. The maximization of power in politics and the maximization of rents in the economy should be perceived as a rational goal of the ruling groups, who achieved it in Russia in the wake of regime changes and market reforms. Some analyses of the dynamics of the rules of the game in the political and economic arenas after the Soviet collapse have demonstrated that complex transformations make it easier to achieve these goals, where they otherwise could be more difficult (Hellman, 1998; Sonin, 2003; Aslund, 2007; Mendras, 2011; Hale, 2014; Gel'man, 2015). The neopatrimonial politico-economic order has served as an instrument of the ruling groups, and "subversive" institutions have maintained its continuity and solidified the existing configurations of political and economic actors. However, while some leaders of post-Soviet countries were able to maximize their power and rents, others failed to do so. Unlike the "legacy" argument, the focus on purposeful institution-building considers post-Soviet neopatrimonialism as an outcome of conscious "poisoning" of the social and political organism by certain actors belonging to the ruling groups. Yet answering the question of possible cures for this kind of disease is far from straightforward.

The following are the foundational principles of post-Soviet neopatrimonialism as a politico-economic order which defines features of political regimes and mechanisms of governance:

(1) Rent extraction is the major goal and substantive purpose of governing the state at all levels of authority;

(2) The mechanism of governing the state tends towards a hierarchy (the "power vertical") with only one major center of decision-making, which claims a monopoly on political power (the "single power pyramid") (Hale, 2014);

(3) The autonomy of domestic political and economic actors vis-à-vis this center is conditional; it can be reduced and/or abolished at any given moment;

(4) The formal institutions which define the framework of power and governance are arranged as by-products of the distribution of resources within the 
"power vertical": they matter as rules of the game only to the degree to which they contribute to rent-seeking (or at least do not prevent it);

(5) The power apparatus within the "power vertical" is divided into several organized groups and/or informal cliques, which compete with each other for access to rents.

These principles are the essence of an informal institutional "core", or de facto constitution, of the neopatrimonial politico-economic order, around which the ruling groups build the shell of formal institutions (such as official constitutions or electoral systems). This shell is not just a camouflage aiming to hide the ugly face of neopatrimonialism; it also serves as a mechanism of authoritarian power-sharing which reduces the risk of regime changes and maintains a balance of power among the insiders of the winning coalition (Svolik, 2012). Although authoritarianism in both its "electoral" (Schedler, 2013) and "classical" ("hegemonic") (Howard, Roessler, 2006) forms is a by-product of neopatrimonialism in the political arena, its manifestations should not be reduced to authoritarian regimes and risks of their subversion. These risks emerge when the political monopolies of ruling groups are undermined and autonomy of political and economic actors becomes limited in certain ways, so regime changes or threats thereof are not so rare. But if these risks are averted, then neopatrimonial governance may become invincible (if one puts aside risks stemming from exogenous shocks for respective countries).

The symbiosis of the informal neopatrimonial "core" and the formal shell which outwardly seems to share features with advanced states and markets, ranging from legally independent courts to the commercial operations of state-owned companies such as $\mathrm{RZhD}$, maintains a stable yet inefficient equilibrium (Gel'man, 2012). This fact explains a paradox which has been described by scholars of Africa: under conditions of neopatrimonialism, the state of affairs in a given country should inevitably worsen, but in fact disequilibrium is relatively rare (Erdmann, Engel, 2006). Formal institutions are not the only reason for this. The stable increase of rent in post-Soviet Russia (given high oil prices) has also helped to maintain the status quo despite short-term economic troubles (Aslund, Guriev, Kuchins, 2010). Unlike the African neopatrimonial states and regimes which are widely perceived as "dictatorships of stagnation" (Bratton, van de Walle, 1994, 1997; Erdmann, Engel, 2006), post-Soviet Russia displays an opposite trend: the drive for economic growth in the 2000s served as the major source of maintenance of the neopatrimonial politico-economic order. Ruling groups are interested in growth and development not only to increase the amount of rents and to satisfy the appetites of numerous rent-seekers but also because of the need for both domestic legitimation of the political regime (Rogov, 2013), and the legitimation of foreign policy on international arenas. In addition, visible and internationally recognized achievements of growth and development, such as global mega-events (like the Olympic Games, the G8/G20 summits, or the inclusion of universities in the top 100 of world ratings) serve as a source of conspicuous consumption and of status rent both for ruling groups and for societies at large.

Thus, post-Soviet neopatrimonialism implicitly assumes the aspiration of ruling groups to successfully implement a "narrow" program of socio-economic modernization. They aim to achieve a high degree of socio-economic development and to accomplish at least some policy reforms oriented towards attainment of these goals. At the same time, the "broad" agenda of political modernization (which includes democratization and extension of political freedoms) is not openly rejected but either postponed or reduced to naught, similarly to the "virtual liberalization" of Russia during the presidency of 
Dmitry Medvedev (Gel'man, 2015). The agenda of "narrow" modernization is shared not only by the ruling groups of Russia and other post-Soviet countries but also by significant parts of their citizens. To some extent, as an instrument of growth and development this agenda also maintains the neopatrimonial politico-economic order, at least in the short run. ${ }^{3}$

However, under conditions of post-Soviet neopatrimonialism the agenda of "narrow" modernization faces numerous obstacles. First, policy reforms have to be implemented by state bureaucracy (Gel'man, Starodubtsev, forthcoming), despite its poor quality (Worldwide, 2014). Second, policy reforms which may infringe on the interests of influential rent-seekers will be curtailed, especially if their implementation is not endorsed by a powerful coalition of supporters. ${ }^{4}$ Third, in these circumstances policy reforms often lead to unintended and undesired consequences. These consequences depend not only on specific policies in certain areas, but to a great degree on the hierarchical mechanism of governance within the framework of the power vertical and its institutional constraints on policy reforms.

\section{The Power Vertical as a Tool of Neopatrimonial Governance}

The term "power vertical" is usually used to describe the hierarchical model of subnational politics and governance in post-Soviet countries (Gel'man, Ryzhenkov, 2011). It assumes formal and informal subordination of levels of authority and a web of informal exchanges between them (for electoral authoritarian regimes, vote delivery is one of the major resources in these exchanges). But similar mechanisms are employed not only in territorial but also in sectoral governance (including in the public sector). One might observe sectoral power verticals within the law enforcement apparatus, educational institutions, and some NGOs. Private business is also involved in numerous informal exchanges within the power vertical, but it enjoys a broader autonomy. ${ }^{5}$ These exchanges include not only distribution of rents but also compliance (or noncompliance) with formal rules and norms and changes in formal institutions. The power vertical is widely perceived as a legitimate mode of governance because of the possibility of hierarchical control over lower-level officialdom. These perceptions are reinforced by the post-Soviet experience of the 1990s, with its protracted decline of state capacity and major distortions of law and order after the Soviet collapse (Volkov, 2002); this experience serves as an additional argument for the use of the power vertical as a tool of neopatrimonial governance. As Adam Przeworski rightly observed, "Since any order is better than any disorder, any order is established" (Przeworski, 1991: 86). As long as the lower layers of the power vertical are able to distribute resources and perform functions of social patronage, this mechanism of governing territories, enterprises, and organizations persists.

\footnotetext{
${ }^{3}$ Some scholars argue that in the medium term, the agenda of "narrow" modernization may serve as an effective preparation tool for future democratization after the downfall of authoritarian regimes (Treisman, 2014). It is too early to say to what extent these considerations will be relevant with regard to post-Soviet neopatrimonialism.

${ }^{4}$ The failure of police reform in Russia under the presidency of Dmitry Medvedev may serve as a prime example in this respect (Taylor, 2014).

${ }^{5}$ For example, workplace mobilization during the 2011-2012 national elections in Russia was less typical for private enterprises in comparison with state-owned companies and the public sector (Frye et al., 2014).
} 
The use of the power vertical as a pillar of the neopatrimonial politico-economic order leads to a major increase in agency costs and to the aggravation of principal-agent problems within the hierarchy of governance (Sharafutdinova, 2010; Gel'man, Ryzhenkov, 2011). For instance, while in China these problems in the system of territorial governance are partially resolved via competition among local agents and their mutual policing (provincial Communist bosses can be promoted to the national leadership if and when they demonstrate excellent economic performance), post-Soviet Russia employ other solutions. Eugene Huskey labels them "the politics of redundancy" (Huskey, 1999). In other words, parallel hierarchies in charge of control and monitoring emerge at various layers of the power vertical; presidential administrations exert political control over governments, presidential representatives do the same vis-à-vis governors and city mayors, and so forth. Numerous state agencies in charge of regulation and monitoring in various sectors of the economy, with their own territorial branches, are also used as tools of control. At first sight, strict adherence to top-down hierarchical relations against the interests of the power vertical's lower echelons should require the threat of punishment of subordinated actors by the top leadership for virtually all instances of wrongdoing, misbehavior, and poor performance. But in fact, the systematic use of repression against lower-level officials of the power vertical is relatively rare; the hierarchy of the power vertical is far from an army-like chain of command, and it operates according to a different logic.

The popular argument that the power vertical serves merely as a tool of subordination and control is only partially true. One should take into account its other functions. As Barbara Geddes notes, 'the central problem for authoritarian regimes is the creation of an appropriate set of incentives to shape behavior of their own officials' (Geddes, 1994: 193). From this point of view, the power vertical should be considered as a provider of selective informal incentives. The status of its insiders rewards them with extra benefits as they receive certain exclusive gains unavailable for those actors not included in the power vertical. The major condition for lower-level beneficiaries is that their opportunistic behavior should not prevent the political leadership from achieving its strategic policy goals. In the most general sense, these goals include the preservation of a stable economic and social order, in which the ruling group runs unchallenged and maintains the relative well-being of the population-at-large. Thanks to economic growth and development, the principal at the top of the power vertical pyramid is able to reward his agents through access to rents. Thus, corruption is not merely a side effect of bad governance, but rather an indispensable part of the mechanism of neopatrimonial governance within the framework of the power vertical.

In its quest to maintain the loyalty of local actors, the political leadership is forced to use both carrots and sticks. The multiple tools of control include not only the appointment, dismissal, and replacement of officials, but also exclusion from access to rents and "contract-ordered" criminal investigations against officials and businessmen, or threats thereof with the use of kompromat (Ledeneva, 2013). These instruments not only maintain loyalty to the power vertical, but are also used as an additional mechanism of control. Almost every actor can easily be accused of criminal acts, and the threat of criminal prosecution is an even more efficient tool for maintaining control than its actual use. As a consequence, actors are genuinely interested in the successful implementation of policies which serve both the goals of political leadership and their own self-interest. One should note that punishments take place under two kinds of circumstances: either because actors' rent seeking activities contradict the policy goals 
of the political leadership or (more rarely) because their poor performance undermines the legitimacy and stability of the politico-economic order.

Thus, the power vertical is a relatively cheap (in terms of agency costs) and successful (in terms of incentives) solution to the principal-agent problem: the principal informally offers rent access to loyal and capable agents. This mechanism maintains the capacity of neopatrimonial governance in multiple political and socio-economic arenas. The state serves both the collective interests of the power vertical's insiders as a group (or rather, as an estate), and the private interests of all its agents, ranging from presidents and prime ministers to local school directors who are allowed to steal public money designated for renovation of the school building if during elections they will deliver votes to the polling station located at their school. As for outsiders to the power vertical, the very opportunity for access to rents is a major incentive not only for political loyalty but also for personal career choices: for example, many graduates of Russian universities admit that the goal of their pursuit of higher education was a chance to get jobs in the state apparatus or in major state-owned companies such as Gazprom (Petrov, Yadukha, 2009).

Within the post-Soviet context this mechanism of governance demonstrates some specific features. They include, inter alia, the specific divisions among and between the layers and corridors of the state machinery, and competition between various agencies and informal cliques for rent access and for positions in the informal hierarchy of decision-making. For example, Russian law enforcement agencies experience stiff competition between the Office of the Prosecutor General and the Investigative Committee, despite the fact that the latter agency is formally subordinated to the former (Volkov et al., 2013). Russian big business demonstrates a rivalry between Gazprom and Rosneft (the latter emerged as a competitor almost by chance) (Gustafson, 2012), and so forth. But these contradictions are mostly structural, because both state agencies and state-owned companies are affected by sectoral power verticals which link lowerlevel actors to their patrons at higher levels of authority or even in the top leadership. This mechanism plays a powerful role in the informal system of governance because it cannot be bypassed in the process of appointments or dismissals in the lower echelons of the power vertical, and it is important for the survival of all actors in their behind-thescenes struggles against powerful competitors.

In the media discourse, these phenomena are often regarded as the "new Politburo" or the "struggle between Kremlin's towers" (Petrov, 2011), but such labels are rather superficial. Parallels between the power vertical under the post-Soviet neopatrimonial politico-economic order and the Soviet hierarchical model of governance do not touch upon the basic differences in goal-setting, institutions, and incentives. In the Soviet Union, the Communist Party exerted control over the state apparatus and was able to impose sanctions on violators of formal and informal rules of the game. In the postSoviet environment, the personalist nature of neopatrimonialism and the interests of powerful members of winning coalitions set up other constraints: all personnel decisions must include the maintenance of the balance between sectoral power verticals and cliques, and the use of "divide and conquer" tactics for prevention of open intra-elite conflicts. The emergence of informal alliances and rivalries between actors who compete for rent access is an unavoidable side effect of the informal distribution of resources among agents. This competition drastically increases agency costs and worsens rather than improves the quality of governance. Although the fruits of economic growth may satisfy the appetites and interests of the most powerful rentseekers and diminish their rivalries, these contradictions cannot be eliminated. 
If the power vertical did not receive demands for policy reforms from the top leadership, and only reproduced the status quo, then even given a minimal inflow of resource rent and very sluggish (if not zero) economic growth, this model of governance could reproduce itself similarly to that of some neopatrimonial African states (Erdmann, Engel, 2006). However, the imperative of "narrow" modernization drives the political leadership to launch numerous policy reforms, which are to be implemented by agents of the power vertical at various levels of authority. These reforms imply not only structural changes (such as the establishment of new agencies) but also changes of goals and criteria for policy evaluation. Bureaucrats and officials have to demonstrate "efficiency", which is broadly understood as the achievement of certain formal indicators, ranging from conduction of auctions in the state procurement system to a certain quantity of scholars' publications in journals listed in the Web of Science and Scopus databases. Policy reforms often destabilize the power vertical, but their effects on the quality of governance are not so obvious. Sometimes the state of affairs even degrades vis-à-vis the previous status quo, as in the case of the replacement of old Kaganovichs with new Yakunins. Why do the policy reforms sometimes have such dismal results?

\section{The Temptation of Policy Reforms}

The role of the power vertical in neopatrimonial governance is important for an understanding of "narrow" modernization as a set of socio-economic policy reforms. The top political leadership is the sole mastermind of reform programs and plans. ${ }^{6}$ These programs are developed by both ideationally-driven experts, contracted by the power vertical, and career-driven policy entrepreneurs from among the mid-range officials, and sometimes even by invited foreign consultants (Easterly, 2001). Reform programs are implemented by various layers and hallways of the power vertical, while the political leadership retains a monopoly on policy evaluation. ${ }^{7}$ These conditions favor an "insulation" of reforms and reformers from the pernicious influence of interest groups and public opinion (Geddes, 1994), yet they also impose almost unavoidable constraints on policy reforms in virtually all areas. The main constraint is related to the very fact that the neopatrimonial institutional "core" is untouchable by any reform: at best, they can affect only formal institutional shells. No wonder that many reform proposals are already planned to be partial, incomplete and compromised measures even at the preparatory stage (not to mention further decision-making and implementation). Initially good intentions are emasculated and perverted by rent seekers, who are interested in privatization of gains from policy reforms and in socialization of their losses. These problems are admitted by reformers themselves, who often already expect these negative outcomes at the beginning of policy planning.

To some extent, the distortion of policy reforms has become a side effect of the mechanisms of separation of power in post-Soviet Russia. The presidentialparliamentary institutional design (Shugart, Carey, 1992) assigns a secondary role to parliament and political parties, while popularly elected heads of the state unilaterally

\footnotetext{
${ }^{6}$ Although alternative policy programs are proposed by independent experts from time to time, they usually remain ignored by political leaders.

${ }^{7}$ Policy evaluation is not an arbitrary personalist choice by political leaders: it takes into account the interests of the members of the winning coalition as well as public opinion. But under conditions of neopatrimonialism, political leadership enjoys more room for maneuver than in most democracies.
} 
hire and fire governments and prime ministers. The government, in turn, enjoys a limited autonomy and performs the technical (but not political) function of implementing decisions made by the head of state. This mechanism is fairly relevant for neopatrimonial governance: the government is more or less an administrative office of the state, which in itself is a fiefdom of political leaders and their winning coalitions (Gel'man, Starodubtsev, forthcoming). Hence, the cabinet of ministers is highly fragmented: it is neither a group of officials who are politically responsible before the parliament nor a team of professionals who share common policy goals and methods. The prime minister is responsible for coordinating this complex web of relationships. $\mathrm{He} / \mathrm{she}$ is dependent on numerous deputy prime ministers who supervise various state agencies (and some of these - first and foremost, power ministries and the law enforcement apparatus - are directly responsible before the head of state). As a result, policy-making under these conditions turns into a complex and often inefficient series of bargains and ad hoc agreements between several state agencies, and is often perceived by observers as a very difficult process (Gilman 2010). Such complexity contributes to a status quo bias in many policy areas.

Under these circumstances, a direct appeal by reformers to the head of state, who might be interested in successful policy reforms in certain areas and consider them a personal priority, might be the most efficient policy-making strategy. In some cases, open support from the top political leadership has enabled reformers to overcome resistance from various segments of the state apparatus and implement their policy proposals via "manual control". The Russian tax reform of the early 2000s, conducted by the ministers of finance and economic development and their teams with the explicit support of Vladimir Putin, was one such "success story" (Appel, 2011; Gel'man, Starodubtsev, forthcoming). But the other side of the coin is apparent: the number of personal priorities of top political leaders is limited, and implementation of some reforms may close the door to other policy changes. Moreover, if some priorities and/or approaches to policy reforms do not show visible success, then incentives for further changes (if not for the agenda of "narrow" modernization as a whole) may be undermined. ${ }^{8}$ Furthermore, the very drive towards policy reforms heavily depends on the prospects for political leaders - authoritarian regimes are more vulnerable to these considerations than democracies. For electoral authoritarian regimes, the "window of opportunity" for policy changes closes before election cycles, which are crucial for the survival of regimes and leaders (Hale, 2014); in "classical" ("hegemonic") authoritarian regimes (Howard, Roessler, 2006), incentives for policy reforms tend to decline over time while long-standing personalist leaders remain in power.

But the major problem of post-Soviet neopatrimonialism for policy reforms is related to its informal institutional core, which not only inhibits changes to the formal institutional shell, but exerts a distorting influence on the directions and effects of policy changes. In essence, any policy reforms cause major redistributive consequences. In political terms, policy adoption and implementation implies a process of building coalitions of potential beneficiaries of the reforms and the accommodation of their interests with those of the potential losers. These negotiations often damage the quality of policy-making because of the influence of "distributional coalitions", which may block any positive changes

\footnotetext{
${ }^{8}$ The experience of the 2005 reform of social benefits in Russia is a prime example: poorly prepared and imperfectly funded changes which affected many pensioners and other disadvantaged social groups caused social protests in many cities. After that, policy changes in a number of other areas were stopped, and the very discourse of "reform" became taboo among officials (Wengle, Rusell 2008; Pis'mennaya, 2013).
} 
(Olson, 1982). In the wake of democratization, these tendencies often contributed to populist policies (as in Latin America in the 1980s), and these risks were among the major concerns of Russian reformers in the 1990s (Zhestkim kursom, 1990; Mau, 1999). However, the neopatrimonial politico-economic order is also compatible with distributional coalitions, and their influence has increased over time (Shirikov, 2010). Despite the populist rhetoric of post-Soviet neopatrimonial leaders, the major beneficiaries of this politico-economic order are small privileged groups of rent seekers. Thus, the power vertical became a mechanism of rent sharing among members of winning coalitions, who transferred the costs of policy reforms to other actors and/or to society at large. They do not face the constraints imposed by formal institutions; rather, the informal institutional core of the neopatrimonial politico-economic order is deliberately tuned for distributive effects of this kind. Thus, the privatization of benefits and socialization of losses have become inevitable effects of policy reforms under neopatrimonialism. The rapid economic growth of the 2000s to some extent diminished these effects, but if and when Russia faced certain crises, the contradictions of policy reforms became explicit. ${ }^{9}$ Their distributive effects increase until the potential decline of inflow of rents causes major conflicts between rent seekers.

The reform of RZhD clearly illustrates these tendencies. Yakunin, being CEO of the holding and one of the key members of the winning coalition, maximized benefits for $\mathrm{RZhD}$ and for himself. The company became a monopolist holding, managed by Yakunin on behalf of the Russian state in the manner of a fiefdom, without any external control over its operations. The benefits of the reforms for the company were apparent: $\mathrm{RZhD}$ no longer had to subsidize unprofitable commuter trains, was able to unilaterally set up tariffs, received outstandingly high fees for the use of its assets by its own subsidiaries and prevented competition on the market. Costs were transferred not only to passengers (individual consumers of monopolist services) but also to all taxpayers. As long as regional budgets were able to satisfy RZhD's appetites, this situation was considered unacceptable only by opposition activists (Navalny, 2014, 2015a), and did not attract major public attention. The transferring of costs from regional to federal budgets may have diminished the salience of this problem for a while but does not change its causes.

The other problem of policy reforms under neopatrimonialism is related to the very fact that the hierarchical power vertical is the only (imperfect) instrument of their implementation. Reformers and their patrons among the top political leaders assume nearly by default that without strict and tight top-down control, the lower layers of the power vertical have no incentives even for their routine performance (let alone policy changes). Given the lack of other mechanisms of accountability (fair elections, free media, civil society NGOs, public opinion etc.), these concerns are quite reasonable. The good intentions of efficient governance are opposed by the weak incentives for policy changes in other political and institutional contexts (Pressman, Wildavsky, 1973). And post-Soviet Russia is by no means exceptional in this respect. Yet the neopatrimonial politico-economic order is the least likely environment for successful implementation of major policy reforms. Since the list of beneficiaries of these changes is limited to a narrow group of rent seekers, reformers have to force other actors to

\footnotetext{
${ }^{9}$ In Russia's case, these redistributive effects resulted in a sharp increase in military expenditure and simultaneous cutting of expenditures on public health and education; the proposal of a reform of school education, which aimed to abolish free schooling for pupils (Lyubimov, 2015), became a logical extension of this approach to policy reforms.
} 
conduct reforms which may not bring them any benefits. At the same time, policy programs and plans of reform are based upon the logic of "high modernism" (Scott, 1998): the criteria for successful implementation of changes by the lower layers of the power vertical are reduced to a number of formal quantifiable indicators. ${ }^{10}$ The formalization of these requirements to some extent aims to reduce excessively high agency costs within the framework of the power vertical. However, this approach contributes to the spiral of overregulation: virtually every new policy change results in a drastic increase of the scope and density of regulation of almost all routines at the lower layers. Hence, the amount of paperwork and related costs skyrockets - police officers, school teachers, medical doctors and all personnel on the ground in many organizations (both state and private) are mired in producing numerous reports instead of conducting their primary job functions. As a result, the very goals of policy changes are replaced by the attainment of required numbers in reports at any cost: these reports became the major if not the only criterion of evaluation of policy performance.

The system of reporting in the law enforcement agencies, which focuses on the percentage of criminal statistics vis-à-vis respective previous periods, only aggravates numerous pathologies and replaces the task of combating crime (Volkov et el., 2013; Paneyakh, 2014). Similarly, numerous inspection agencies discover those violations of laws which require the least effort to detect and prove. The introduction of the Unified State Exam (EGE), the new mechanism of assessment of high school graduates in various regions of Russia, serves as an even more notorious example of this approach (Gel'man, Starodubtsev, forthcoming). Soon after its introduction in 2009, the presidential administration included the proportion of school graduates who fail to pass the EGE into the list of criteria for assessment of the performance of regional chief executives (Reuter, Robertson, 2012). This innovation encouraged regional and local officials (ranging from heads of education departments to school teachers) to minimize the number of failures on exams every year, causing numerous prominent scandals (such as the over-performance of school graduates in republics of the North Caucasus). At last, in 2014, the list of criteria was changed again, and regional chief executives could no longer be punished for the failures of teenagers in the EGE. But due to these changes, the percentage of failures could greatly increase, resulting in schools' performances worsening vis-à-vis their previous results. As such, the requirements for passing the EGE were eased to such a degree that achieving minimally acceptable grades was not difficult for even the least capable pupils (Lyubimov, 2015).

Another case of policy reforms is the attempt to improve the business environment in Russia in accordance with Putin's May 2012 decree. The key indicator chosen for implementing these changes was Russia reaching $20^{\text {th }}$ place in the annual global report Doing Business, produced by the World Bank. This report is based on evaluation of conditions for small and medium businesses via analysis of regulatory frameworks and surveys of entrepreneurs. Although most analysts were skeptical about the chances of such progress (in 2012 Russia was in $120^{\text {th }}$ place), in the 2015 annual report Russia reached $62^{\text {nd }}$ place out of 189 . This achievement, however, was possible because the World Bank experts changed the methodology of their report and included more indicators of subnational regulations: the changing set of criteria elevated Russia's rank by 30 places in comparison with the 2014 annual report (Doing Business, 2015).

${ }^{10}$ One example is Putin's May 2012 decrees, which called for the percentage of articles published by Russian scholars and scientists in Web of Science journals to be raised by $2.44 \%$ by 2020 . 
Regardless of Russia's ranking in World Bank reports, the problems for doing business as such were very different: the impressive progress of quantitative indicators was achieved at a moment of stagnation (if not recession) in the Russian economy, recordhigh capital flight, etc. Needless to say, these approaches to post-Soviet policy reforms in various areas brought only partial and incomplete results at best, or even became limited to short campaigns which included the construction of Potemkin villages and contributed to the waste of resources, similarly to their Soviet-era predecessors.

Does this mean that the agenda of "narrow" modernization has no hope of fulfillment under conditions of post-Soviet neopatrimonialism? This question is not straightforward to answer. The inflow of resource rents in Russia and other post-Soviet states in the 2000s enabled at least partial implementation of policy reforms, and in some policy areas socio-economic reforms were far from a total failure (for an overview of Russia, see Alexeev, Weber, 2013). But reforming the formal institutional shell without changes in the informal institutional core of post-Soviet neopatrimonialism brought major positive effects only in certain circumstances. If and when policy adoption and implementation did not require the involvement of many layers and hallways of the power vertical, and reformers were "insulated" from numerous rent seekers because of the priorities and sincere support of the top political leadership, then major advancements could be achieved, as in the case of the tax reforms and the establishment of the Stabilization Fund in Russia (Appel, 2011; Zaostrovtsev, 2010; Gel'man, Starodubtsev, forthcoming). But when reformers employ alternative strategies for institutional change in pursuit of the agenda of "narrow" modernization, policy reforms in various areas often result in unexpected and undesired consequences.

\section{"Borrowing” and “Growing” of Institutions: The Vicious Circle?}

Most of the experts involved in the preparation and development of plans and programs of policy changes clearly understand the pernicious effects of the neopatrimonial institutional core on policy reforms. However, being hired by the authorities, they refrain from criticism of major obstacles for the implementation of the latter's policy ideas. Similarly to experts from international organizations (Easterly, 2001), they use an Aesopian language full of euphemisms such as "poor quality of institutions" or "unfavorable institutional environment", referring to numerous "legacies" and "institutional traps". Since the very discussion of major revision of the foundational principles of neopatrimonialism (and hence the rejection of the entire politico-economic order) is a kind of taboo, the experts seek ways not to undermine these obstacles but to bypass or circumvent them. The key idea is not a demolishing of existing informal institutions but rather a parallel establishment of new formal institutions which are based on other principles than the institutional "core" of neopatrimonialism. It is expected that the new formal institutions will be more efficient, and for this reason they may become embedded over time. According to these ideas, parallel institution-building can gradually supplant the informal institutional core and pave the way for a further strengthening of "inclusive" economic institutions (Acemoglu, Robinson, 2012) and, in the distant future, toward a slow step-by-step adoption of "inclusive" political institutions. This approach perfectly fits the logic of "narrow" modernization and leaves reformers wide room for maneuver in institution-building.

In reality, two complementary strategies of institution-building, namely the "borrowing" and "growing" of institutions, have been proposed as possible solutions by a group of Russian scholars (Kuzminov et al., 2005). "Borrowing" implies a transplantation of 
those institutions which have proved their efficiency in a variety of political and institutional contexts (not necessarily Western ones) and could be adopted in Russia for the purposes of economic growth and development without major risk of immediate undermining of the neopatrimonial institutional core. "Growing", by contrast, assumes that new norms, rules and mechanisms of governance in certain policy areas can be initially established as experimental innovations under deliberately designed favorable conditions, and later on may be spread further in these and other areas. In theory, both of these strategies look reasonable and are often suggested by international experts in developing countries (Easterly, 2001). But the practice of post-Soviet neopatrimonialism puts them into a question because of their essential flaws.

The "borrowing" of institutions, which includes transfer of advanced models and practices of governance, is faced with the process dubbed "shitization", or perversion (Zaostrovtsev, 2009). Initially, this term was used to indicate the declining quality of goods produced in Russia with the use of foreign technologies: domestic managers have few incentives to maintain quality control and often intentionally violate technological standards against the background of imperfect quality of corporate governance. Similarly, one might observe perversion of transferred institutions by those actors who conduct their adoption and implementation in post-Soviet Russia. To some extent, this process is inevitable, because the transfer of certain institutions would impose excessively high costs on mid-developed states (including post-Soviet countries). For example, the EGE in Russia is simultaneously used as a final test for school graduates and an entrance exam for universities, while in the US and a number of other countries these two forms of test are conducted separately. The adoption of a cheaper institutional solution caused a number of problems in the implementation of the EGE (Starodubtsev, 2011). But more often the cause of perversion reflects the "interests of those with the bargaining power to devise new rules" (North, 1990: 16). The adaptation of "borrowed" institutions to post-Soviet conditions is accompanied by their intentional and deliberate distortion by powerful actors interested in the preservation and strengthening of the neopatrimonial institutional core.

A typical example of perversion of borrowed institutions is the experience of implementation of the "open government" initiative in Russia under the presidency of Dmitry Medvedev. The idea of a more open and transparent government with active participation of ordinary citizens in policy discussions and the extensive use of modern information technologies was vigorously advocated by Medvedev's team as a part of the political rhetoric of "virtual liberalization" (Gel'man, 2014). The state designated special finding for these purposes, and a minister responsible for open government affairs was appointed to the cabinet. However, the mechanism was adopted from the Western practice of e-government, which assumes the use of the Internet both for provision of state services and for feedback between citizens and the state (including civic legislative initiatives and the like). In the Western political context, e-government works as a complementary mechanism to democratic governance, an addition to free elections, independent media, rule of law, etc. In Russia, however, open government was designed as a substitutive mechanism of governance (Petrov et al., 2014), and intended to work instead of these political institutions, which had been eliminated and/or emasculated in the 2000s. From the viewpoint of governance in the West, egovernment served as an additional tool which helped to increase the efficiency of the post-Weberian state apparatus. But in Russia, open government was considered a substitution for the administrative reform which had failed in the 2000s - and had done so not least because of the work of Medvedev himself, who had been responsible for 
overseeing it while he was serving in the presidential administration (Gel'man, Starodubtsev, forthcoming). It is no wonder that the early promises of open government remained largely unfulfilled; its role was limited to technological issues of the websites of state and municipal agencies and some opportunities for ordinary citizens to submit their letters of complaint via the Web. "Open government" has not empowered Russian citizens. They remain powerless supplicants vis-à-vis officials, who may or may not respond to these complaints at their own discretion. The final episode of perversion of open government occurred in February 2015, when the Foundation for Combating Corruption (led by Navalny) proposed the legislative initiative on ratification of Article 20 of the United Nations Convention against Corruption (UNCAC), which assumed, inter alia, criminalization of illicit enrichment of state officials (Russian authorities previously refused to ratify this part of UNCAC). Navalny and his team gathered 100,000 signatures from Russian citizens via the Web, which was a mandatory condition for further inclusion of this citizen legislative initiative into the parliamentary agenda. But since this proposal was against the interests of Russia's ruling group, the open government board (appointed by state officials) declined the legislative initiatives using flimsy excuses (Navalny, 2015b). The very ideas of openness, transparency and civic activism became irrelevant in this case.

Another approach to developing new formal institutions which aims to constrain the neopatrimonial institutional core is based upon purposeful "growing", or deliberate cultivation of new norms, rules and mechanisms of governance and their gradual extension to new areas and policy fields. This approach includes not only promotion and advancement of spontaneously emerging good practices but also experimental establishment and embedding of new norms, rules and mechanisms of governance by reformers who, in turn, are explicitly or implicitly backed by the political leadership. Since large-scale institutional changes are often countered both by the power vertical and by public opinion, the "growing" of institutions sometimes serves to prepare more fertile grounds for certain policy innovations, while the changes' experimental nature allows their details to be tested, thus averting the risks of full-scale institutional failures. From this viewpoint, the "growing" of new institutions is an appropriate technological solution which also makes it possible to overcome resistance to major policy reforms. The EGE in Russia had no chances of being backed by educators or by public opinion, so in 2001 it was initially proposed as an "experiment". Later on, the geographical scope of this "experiment" expanded, and by 2008 the full-fledged adoption of the EGE as the only mechanism of assessment of school graduates became unavoidable. However, the side effect of this "success story" was the lack of legitimacy of the EGE in the eyes of many Russian citizens, and endless attempts to diminish its ultimate influence on entrance to universities (Starodubtsev, 2011; Gel'man, Starodubtsev, forthcoming). But experiment as a method of policy reform is a double-edged sword: its poor conduct and/or inefficient implementation can put an end to institutional innovations. ${ }^{11}$

In most cases, failures of "growing" of new institutions are caused by political rather than technological factors. Most large-scale institutional innovations are rather costly, face resistance from various rent seekers and bureaucratic inertia, and also need public

\footnotetext{
${ }^{11}$ As for reforming school education in Russia, the failed implementation of state financial obligations (so-called "educational vouchers"), which were intended to link the amount of state funding for university education of school graduates with their EGE results, is indicative. It was initially proposed in a number of regions, but had no positive effects, and the very idea has been buried (Starodubtsev, 2011).
} 
legitimation. The patronage of the top political leadership is necessary but often insufficient for accomplishment of these goals. This is why the "growing" of institutions is often accompanied by the use of special organizational devices, known in the Latin American context as "pockets of efficiency" (Geddes, 1994). Their essence is that the political leadership prioritizes a limited number of pet projects, which are implemented not within the framework of the hierarchy of the power vertical, but via deliberately created organizations and groups which enjoy exceptional official status and may operate beyond standard routines. Thanks to their relative autonomy and effective patronage, these organizations and groups may escape from bureaucratic control, bear lower agency costs in comparison with their standard equivalents, and have more room for maneuver thanks to promises of achieving breakthroughs. Sometimes these promises are fulfilled, but this whole game is rather risky. ${ }^{12}$

The economic growth of the 2000s and the inflow of extra revenues and rents gave postSoviet political leaders numerous opportunities to patronize several pet projects, with some hopes of their advancement to successful pockets of efficiency. But the fate of these projects depends upon the further careers of their patrons as well as upon their resource endowment, which is necessary to achieve major effects. In the Russian context, the experience of the major high-tech innovation project Skolkovo is indicative. During Dmitry Medvedev's presidency it served as his top priority and received very generous funding from the Russian state and Big Business, despite serious skepticism from key players in the field (Pynnöniemi, 2014). After Medvedev's departure from the presidential post Skolkovo's funding was greatly reduced, its proposed role as a key driver of technological progress and rapid economic development was nearly forgotten, and several financial scandals finally buried its reputation (Reiter, Golunov, 2015). More recently, economic troubles have led to the shrinkage of the time horizon for planning, and so the post-Soviet political leadership is more interested in short-term achievements from pockets of efficiency, rather than their long-term plans of diffusion of institutional innovations.

Pockets of efficiency are short-lived not only because of the fortunes of political leadership and their changing priorities and problems with continuity of funding. Even if pockets of efficiency perform well and accomplish their initial tasks, they barely survive the subsequent routinization and the loss of exclusive status. At the same time, their good practices are often poorly diffused and may be rejected by other establishments unless they are imposed top-down by the political leadership. Finally, the "pockets" are efficient precisely because of their compactness: when they begin to expand their scope and become "too big to fail", they may face degradation because their modes of governance often copy the institutional core they aimed to combat. The logic of "institutional isomorphism" (Di Maggio, Powell, 1983) suggests that the neopatrimonial core is able to rebuild pockets of efficiency, rather than vice versa, and the potential incubators of new institutions may contribute to rent seeking and serve the goals of the power vertical similarly to their predecessors.

To summarize, one might argue that the parallel presence of the neopatrimonial institutional core and new norms, rules, and mechanisms of governance may be instrumental in policy reforms in certain areas, but cannot resolve their fundamental

\footnotetext{
${ }^{12}$ The "Toy Army" of Peter the Great may be considered as the closest analog for "pockets of efficiency" in Russian history: it served as a launching pad for a regular military establishment. The Soviet atomic bomb and space programs to a great degree relied upon special design bureaus (also known as sharashki), which may be regarded as the Stalinist version of "pockets of efficiency".
} 
contradictions. The neopatrimonial politico-economic order imposes high barriers to the implementation of the agenda of "narrow" modernization (for a review in Russia, see Alexeev, Weber, 2013). Neither the "borrowing" nor "growing" of institutions as such can increase the chances of success of policy reforms. Rather, their plans may be sacrificed for the sake of the survival of regimes, or at a certain point may be launched again, thus contributing to a "vicious circle" of elusive chances for successful socioeconomic advancements. The experience of the neopatrimonial political-economic order in Africa (Easterly, 2001) demonstrates that such a circle's pernicious influence cannot be easily constrained by new norms, rules, and mechanisms of governance; neopatrimonialism can reproduce itself under various conditions.

\section{Concluding Remarks: How to Break the Vicious Circle?}

Are there any chances to ultimately break the vicious circle of post-Soviet neopatrimonialism? The sources of positive answers to this question are connected with possible regime changes after leadership turnover (Treisman, 2014) and with extensive international influence enhanced by globalization (Ledeneva, 2013); these processes are closely linked and interrelated (Levitsky, Way, 2010). Although both arguments sound convincing, a close look at the neopatrimonial politico-economic order in the postSoviet area and beyond might cast a bit of skepticism on these hopeful trends: both regime changes and international influence are necessary yet insufficient conditions for breaking this vicious circle.

Henry Hale, in his comparative study of post-Soviet regime changes, has demonstrated that the political dynamics is often cyclical by nature, and leadership changes as such do not result in major changes in the politico-economic order: it seems that the neopatrimonial core will be given a new coat of paint rather than constrained. Scholars of African neopatrimonialism observe that this politico-economic order could survive and reinvent itself regardless of numerous changes of leadership and regime (Bratton, van de Walle, 1994, 1997; Erdmann, Engel, 2006), while only aggravating problems of quality of governance (Easterly, 2001). Such threats are equally real in the post-Soviet context.

With regard to international influence and globalization, one should take into account that the neopatrimonial politico-economic order can adjust to these changes and establish a suitable interface with the outside world without major constraint on its informal institutional core. Becoming a raw material-supplying appendage of advanced countries - first and foremost, of China (a possible future for Russia) - may preserve neopatrimonialism rather than undermine it, as the experience of many African states demonstrates. As Levitsky and Way vigorously argue, even well-developed linkages with the West have a limited impact on non-democratic regimes if they do not coincide with the extensive use of Western leverage (Levitsky, Way, 2010). This disjuncture between involvement in a global web of trade, migration and education, and preservation of the neopatrimonial politico-economic order in domestic arenas, results from the insulation of neopatrimonialism from outside influence with the use of state sovereignty as a tool for maintaining the status quo. Under neopatrimonialism, state sovereignty serves as a shield for ruling groups; it helps to insulate them from the weakening of political and economic power and to protect them from undesirable institutional changes. The idea of defense of sovereignty at any cost (including banning foreign NGOs and limiting the import of Western foods as well as cultural products) is not paranoia but a rational strategy of the Russian political leadership, which claims 
sovereignty of the country while having in mind the preservation and enlargement of their personal "fur storages". Meanwhile, external constraints on Russia's state sovereignty imposed by advanced countries may (but not necessarily should) create barriers for the neopatrimonial institutional core, and in the longer term lead to a revision of the politico-economic order. From this viewpoint, the experience of Eastern European countries after EU accession and their need to follow the rules of the game of Greater Europe severely reduced the pernicious effects of neopatrimonial "patronal politics" in these countries (Hale, 2014), although it is too early to speak of its full-scale elimination.

However, in the case of Eastern European countries, EU-led external constraints of state sovereignty become possible due to the voluntary choice of their elite and citizens. In Russia this issue is far from the agenda, to put it mildly.. The problem here relates not only to the resistance of Russia's ruling groups and/or the attitudes of its citizens, but also to the incredibly high costs for those nations which may impose constraints on the sovereignty of other states. Even for the EU, attempts to enforce the integration of Eastern European states were quite costly, and this process is far from complete (to put it mildly). For Russia and some other post-Soviet states, the possible costs of externally imposing and enforcing new rules and norms aimed at overcoming neopatrimonialism would be prohibitively high (even if governments and citizens may not resist these efforts in certain circumstances) - unless this politico-economic order becomes a major problem for the West. This is why an absence of external intervention into the neopatrimonial politico-economic order, which would contribute to preserving the status quo, is the more likely scenario: both the fears and the hopes of Westerndriven constraint of sovereignty in post-Soviet area seem unreasonable. However, one cannot exclude the possibility that the further aggravation of Russia's confrontation with the West, which was launched after the 2014 regime change in Ukraine, may turn into a major challenge of this kind. From this viewpoint, Russia's possible defeat in a new Cold War with the West may pave the way to external constraint of its sovereignty and provide certain incentives for a gradual replacement of neopatrimonial political and economic institutions by more inclusive rules and norms. One cannot even imagine the possible level of outstandingly high costs for such a complex transformation of the politico-economic order. Yet the costs of preservation of the vicious circle of postSoviet neopatrimonialism may be even higher for Russia and for the outside world. 


\section{References}

Acemoglu Daron, and James A. Robinson, 2012, Why Nations Fail: The Origins of Power, Prosperity, and Poverty, New York: Crown Business.

Alexeev Michael, and Shlomo Weber, eds., 2013, The Oxford Handbook of the Russian Economy, Oxford: Oxford University Press.

Appel Hilary, 2011, Tax Politics in Eastern Europe: Globalization, Regional Integration, and the Democratic Compromise, Ann Arbor, MI: University of Michigan Press.

Aslund Anders, 2007, Russia's Capitalist Revolution: Why Market Reforms Succeeded and Democracy Failed, Washington, DC: Peterson Institute for International Economics.

Aslund Anders, Sergei Guriev, and Andrew C. Kuchins, eds., 2010, Russia after the Global Economic Crisis, Washington, DC: Peterson Institute for International Economics.

Bratton Michael, and Nicolas van de Walle, 1994, Neopatrimonial Regimes and Political Transitions in Africa, World Politics, 46 (4): 453-489.

Bratton Michael, and Nicolas van de Walle, 1997, Democratic Experiments in Africa: Regime Transitions in Comparative Perspective, Cambridge: Cambridge University Press.

Bueno de Mesquita Bruce Bueno, and Alastair Smith, 2011, The Dictator's Handbook:

Why Bad Behavior is Almost Always Good Politics, New York: Public Affairs.

Derluguian Georgi, 2005, Bourdieu's Secret Admirer in the Caucasus: A World-System Biography, Chicago: University of Chicago Press.

Di Maggio Paul J., and Walter W. Powell, 1983, The "Iron Cage" Revisited: Institutional Isomorphism and Collective Rationality in Organizational Analysis, American Sociological Review, 48 (2): 147-160.

Doing Business, 2015, Doing Business 2015: Going Beyond Efficiency, The World Bank, Washington, DC. http://www.doingbusiness.org/reports/global-reports/doing-business-2015 (accessed May 31, 2015).

Dutkiewicz Piotr, and Richard Sakwa, eds., 2013, 22 Ideas How to Fix the World: Conversations with the World's Foremost Thinkers, New York: New York University Press.

Easterly William R., 2001, The Elusive Quest for Growth: Adventures and Misadventures in the Tropics, Cambridge, MA: MIT Press.

Eisenstadt S.N., 1978, Revolution and the Transformation of Societies: A Comparative Study of Civilizations, New York: Free Press.

Erdmann Gero, and Ulf Engel, 2006, Neopatrimonialism Revisited: Beyond a Catch-all Concept, Hamburg: German Institute for Global and Area Studies, GIGA Working Paper № 16.

Fisun Oleksandr, 2012, Rethinking Post-Soviet Politics from a Neopatrimonial Perspective, Demokratizatsiya: The Journal of Post-Soviet Democratization, 20 (2); 87-96.

Frye Timothy, Ora John Reuter, and David Szakonyi, 2014, Political Machines at Work: Voter Mobilization and Electoral Subversion in the Workplace, World Politics, 66 (2): 195-228.

Gaaze Konstantin, 2015, Reformy po krugu: president vernul elektrihki, kotorye sam otmenil [The Circle of Reforms: The President Restored Commuter Trains, Which He Canceled Previously], Forbes.ru, 5 February http://www.forbes.ru/mneniya-column/vertikal/279533reformy-po-krugu-prezident-vernul-elektrichki-kotorye-sam-otmenil (accessed May 31, 2015).

Geddes Barbara, 1994, Politician's Dilemma: Building State Capacity in Latin America, Berkeley, CA: University of California Press.

Gel'man Vladimir, 2012, Subversive Institutions, Informal Governance, and Contemporary Russian Politics, Communist and Post-Communist Studies, 45 (3-4): 295-303.

Gel'man Vladimir, 2014, The Rise and Decline of Electoral Authoritarianism in Russia, Demokratizatsiya: The Journal of Post-Soviet Democratization, 22 (4): 503-522.

Gel'man Vladimir, 2015, Authoritarian Russia: Analyzing Post-Soviet Regime Changes, Pittsburgh, PA: University of Pittsburgh Press.

Gel'man Vladimir, and Sergei Ryzhenkov, 2011, Local Regimes, Sub-National Governance, and the "Power Vertical" in Contemporary Russia, Europe-Asia Studies, 63 (3): 449-465. 
Gel'man Vladimir, and Andrey Starodubtsev, forthcoming, Opportunities and Constrains of Authoritarian Modernisation: Russian Policy Reforms of the 2000s, Europe-Asia Studies.

Gilman Martin, 2010, No Precedent, No Plan: Inside Russia's 1998 Default, Cambridge, MA: MIT Press.

Gustafson Thane, 2012, Wheel of Fortune: The Battle for Oil and Power in Russia. Cambridge, MA: Harvard University Press.

Hale Henry E., 2014, Patronal Politics: Eurasian Regime Dynamics in Comparative Perspective, Cambridge: Cambridge University Press.

Hellman, Joel, 1998, Winners Take All: The Politics of Partial Reform in Postcommunist Transitions, World Politics, 50 (2): 203-234.

Howard Marc Morje, and Philip G. Roessler, 2006, Liberalizing Electoral Outcomes in Competitive Authoritarian Regimes, American Journal of Political Science, 50 (2): 365-381.

Huskey Eugene, 1999, Presidential Power in Russia, Armonk, NY: M.E. Sharpe.

Jowitt Kenneth, 1983, Soviet Neotraditionalism: The Political Corruption of a Leninist Regime, Soviet Studies, 35 (3): 275-297.

Khusainov Farid, 2015, Zheleznye dorogi i rynok, [Railways and the Market] Moscow: Nauka.

Kuzminov Yaroslav, Vadim Radaev, Andrei Yakovlev, and Yevgeny Yasin, 2005, Instituty: ot zaimstvovaniya $\mathrm{k}$ vyrashchivaniyu (opyt rossiiskikh reform i vozmozhnosti kul'tivirovaniya institutsional'nykh izmenenii) [Institutions: From Borrowing to Growing (The Experience of Russian Reforms and Opportunities to Cultivate Institutional Changes], Voprosy ekonomiki, 5: 5-27.

Ledeneva Alena V., 2013, Can Russia Modernise? Sistema, Power Networks, and Informal Governance, Cambridge: Cambridge University Press.

Levitsky Steven, and Lucan A. Way, 2010, Competitive Authoritarianism: Hybrid Regimes after the Cold War, Cambridge: Cambridge University Press.

Lyubimov Lev, 2015, Ne nuzhno vsem vydavat' attestaty. Pochemu v Rossii pora menyat' podkhod k obucheniyu v shkolakh [No Need to Give School Certificates to Everyone: Why Russia Should Change Approaches to School Education], Lenta.ru, 19 February http://lenta.ru/articles/2015/02/19/school/ (accessed May 31, 2015).

Mau Vladimir, 1999, Ekonomicheskaya reforma skvoz' prizmu konstitutsii i politiki [Economic Reform Through the Prism of Constitution and Politics], Moscow: Ad Marginem.

Mendras, Marie, 2011, Russian Politics: The Paradox of a Weak State, New York: Columbia University Press.

Navalny Alexei, 2014, Khroniki genotsida russkikh [Chronicles of Genocide of Russians], navalny.com, 24 December. https://navalny.com/p/4036/ (accessed May 31, 2015).

Navalny Alexei, 2015a, Problema elektrichek, likbez ot FBK [The Problem of Commuter

Trains: $\mathrm{ABC}$ from Fund for Combatting Corruption], navalny.com, 5 February https://navalny.com/p/4107/ (accessed May 31, 2015).

Navalny Alexei, 2015b, Dlya bor'by s korruptsiei v pravitel'stve net kvoruma [The Government Lacks Quorum for Combatting Corruption], navalny.com, 9 February https://navalny.com/p/4117/ (accessed May 31, 2015)

North Douglass C., 1990, Institutions, Institutional Changes, and Economic Performance, Cambridge: Cambridge University Press.

North Douglass C., John Joseph Wallis, and Barry R. Weingast, 2009, Violence and Social Orders: A Conceptual Framework for Interpreting Recorded Human History. Cambridge: Cambridge University Press.

Offe Claus, 1991, Capitalism by Democratic Design? Democratic Theory Facing the Triple Transition in East Central Europe, Social Research, 58 (4): 865-892.

Olson Mancur, 1982, The Rise and Decline of Nations: Economic Growth, Stagflation, and Social Rigidities, New Haven, CT: Yale University Press.

Paneyakh Ella, 2014, Faking Performances Together: Systems of Performance Evaluation in Russian Enforcement Agencies and Production of Bias and Privilege, Post-Soviet Affairs, 30 (2-3): 115-136. 
Pis'mennaya Evgeniya, 2013, Sistema Kudrina: Istoriya Klyuchevogo Ekonomista Putinskoi Epokhi [The Kudrin's System: A Story of Key Economist of Putin's Age], Moscow, Mann, Ivanov and Ferber.

Pittman Russell, 2013, Blame the Switchman? Russian Railways Restructuring after Ten Years, in Michael Alexeeev and Shlomo Weber, eds., The Oxford Handbook of the Russian Economy, Oxford: Oxford University Press, 490-513.

Petrov Ivan, and Viktor Yadukha, 2009, Molodezh' mechtaet o trube [The Youth Dreams about the Pipe], rbc.ru, 27 May, http://rbcdaily.ru/politics/562949979000840 (accessed May 31, 2015).

Petrov Nikolay, 2011, Nomenklatura and the Elite, in Maria Lipman and Nikolay Petrov (eds.), Russia in 2020: Scenarios for the Future, Washington, DC: Carnegie Endowment for International Peace, 2011, 499-530.

Petrov Nikolay, Maria Lipman, and Henry E. Hale, 2014, Three Dilemmas of Hybrid Regime Governance: Russia from Putin to Putin, Post-Soviet Affairs, 30 (1): 1-26.

Pipes Richard, 1974, Russia under the Old Regime, New York: Scribner.

Pop-Eleches Grigore, 2007, Historical Legacies and Post-Communist Regime Change, Journal of Politics, 69 (4): 908-926.

Pressman Jeffrey L. and Aaron B. Wildavsky, 1973, Implementation, Berkeley, CA: University of California Press.

Przeworski Adam, 1991, Democracy and the Market: Political and Economic Reforms in Eastern Europe and Latin America, Cambridge: Cambridge University Press.

Pynnöniemi Katri, 2014, Science Fiction: President Medvedev's Campaign for Russia's "Technological Modernization", Demokratizatsiya: The Journal of Post-Soviet Democratization, 22 (4): 605-626.

Reiter Svetlana and Ivan Golunov, 2015, Rassledovanie RBK: Chto sluchilos' so Skolkovo [RBK Investigation: What Happens with Skolkovo], rbc.ru, 23 March

http://daily.rbc.ru/special/business/23/03/2015/5509710a9a7947327e5f3a18 (accessed May 31, 2015)

Reuter Ora John and Graeme B. Robertson, 2012, Subnational Appointments in Authoritarian Regimes: Evidence from Russian Gubernatorial Appointments, Journal of Politics, 74 (4): 1023-1037.

Robinson Neil, 2011, Russian Patrimonial Capitalism and the International Financial Crisis, Journal of Communist Studies and Transition Politics, 27 (3-4): 434-455.

Robinson Neil, 2014, The Political Origins of Russia's 'Culture Wars', Limerick: University of Limerick, Department of Politics and Public Administration.

Rogov Kirill, 2013, Forty Years in the Desert: The Political Cycles of Post-Soviet Transition', in Maria Lipman and Nikolay Petrov, eds., Russia 2025: Scenarios for the Russian Future, London: Palgrave Macmillan, 18-45.

Schedler Andreas, 2013, The Politics of Uncertainty: Sustaining and Subverting Electoral Authoritarianism, Oxford: Oxford University Press.

Schlumberger Oliver, 2008, Structural Reform, Economic Order, and Patrimonial Capitalism, Review of International Political Economy, 15 (4): 622-649.

Scott James C., 1998, Seeing Like a State: How Certain Schemes to Improve the Human Condition Have Failed, New Haven, CT: Yale University Press.

Sharafutdinova Gulnaz, 2010, Subnational Governance in Russia: How Putin Changed the Contract with His Agents and the Problems It Created for Medvedev, Publius, 40 (4): 672696.

Shirikov Anton, 2010, Anatomiya bezdeistviya: politicheskie instituty $i$ byudzetnye konflikty v regionakh Rossii, St Petersburg: European University at St.Petersburg Press.

Shleifer Andrei and Daniel Treisman, 2014, Normal Countries: The East 25 Years after Communism, Foreign Affairs, 93 (6) http://www.foreignaffairs.com/articles/142200/andreishleifer-and-daniel-treisman/normal-countries (accessed May 31, 2015).

Shugart Matthew, and John Carey, 1992, Presidents and Assemblies: Constitutional Design and Electoral Dynamics. Cambridge: Cambridge University Press. 
Sonin Konstantin, 2003, Why the Rich May Favor Poor Protection of Property Rights, Journal of Comparative Economics, 31 (4): 715-731.

Starodubtsev Andrey, 2011, Istoriya odnoi reformy: EGE kak primer institutsional'nogo peresnosa [The Story of One Reform: EGE as the Case of Institutional Transfer], Working Paper M-24/11, European University at St. Petersburg, Center of Modernization Studies. http://eu.spb.ru/images/M center/preprint Starodubtsev.pdf (accessed May 31, 2015).

Svolik Milan, 2012, The Politics of Authoritarian Rule, Cambridge: Cambridge University Press.

Taylor Brian, 2014, The Police Reform in Russia: Policy Process in a Hybrid Regime, Post-Soviet Affairs, 30 (2-3): 226-255.

Treisman Daniel, 2014, Income, Democracy, and Leader Turnover, American Journal of Political Science, early view publication, DOI: 10.1111/ajps12135.

van Zon Hans, 2008, Russia's Development Problem: The Cult of Power, Basingstoke: Palgrave Macmillan.

Volkov Vadim, 2002, Violent Entrepreneurs: The Role of Force in the Making of Russian Capitalism, Ithaca, NY: Cornell University Press.

Volkov Vadim, Ivan Griroriev, Aryna Dmitrieva, Ekaterina Moiseeva, Ella Paneyakh, Mikhail Pozdnyakov, Kirill Titaev, Irina Chetverikova, and Maria Shklyaruk, 2013, Kontseptsiya kompleksnoi organizatsionno-upravlencheskoi reform pravookhranitel'nykh organov $R F$ [The Concept for Comprehensive Organizational and Managerial Reform of Law Enforcement Agencies in the Russian Federation], St. Petersburg, European University at St. Petersburg Institute for the Rule of Law,

http://www.enforce.spb.ru/images/Issledovanya/IRL_KGI_Reform_final_11.13.pdf (accessed May 31, 2015).

Wengle Suzanne and Michael Rusell, 2008, The Monetisation of L'goty: Changing Patterns of Welfare Politics and Provision in Russia, Europe-Asia Studies, 60 (5): 739-756.

Worldwide, 2014, Worldwide Governance Indicators, 1996-2012, The World Bank, Washington, DC. http://data.worldbank.org/data-catalog/worldwide-governance-indicators (accessed May 31, 2015).

Zaostrovtsev Andrey, 2009, Zakon vseobshchei shitizatsii [The Law of Universal 'Shitization'], fontanka.ru, 11 August. http://www.fontanka.ru/2009/08/11/116/ (accessed May 31, 2015).

Zaostrovtsev Andrey, 2010, Oil Boom and Government Finance in Russia: Stabilization Fund and Its Fate, in: Vladimir Gel'man and Otar Marganiya, eds., Resource Curse and PostSoviet Eurasia: Oil, Gas, and Modernization, Lanham, MD: Lexington Books, 123-147.

Zhestkim kursom, 1990, Zhestkim kursom... Analiticheskaya zapiska Leningradskoi assotsiatsii sotsial'no-ekonomicheskikh nauk [Tough Course: An Analytic Paper of the Leningrad Association for Social and Economic Science], Vek XX i mir, 6: 15-19. 